\title{
戦後の $\mathrm{RC}$ 造校舎のリモデルについて
}

\author{
長 倉 康 彦*1 ・田中 礼 治*2
}

\begin{abstract}
概 要 戦後の $\mathrm{RC}$ 造校舎の建設が始められてから約 40 年を経た。全国小中高等学校校舎の 9 割以上を占めることに なった片側廊下型校舎形式によるこのストックについて, 配值・平面計画の画一性, バラ建てによる機能的欠陥が指摘さ れる。また，この十数年，教育改革にともなう教育の多様化が広く取り上げられ，校舎計画にも大きな変革が要請されて いる。また，相次ぐ地震災害の結果からみた，この RC 造校舎の耐震性能についての問題も残されている。これらの課 題を総論したのち, 今後数十年にわたると考えられる現有 $\mathrm{RC}$ 造校舎ストックの改築・改修システム構築の必要性を説 き, 建築計画および耐震構造計画の両面に分けてその手法を提案し, 今後の研究課題を述べた。

キーワード : 戦後の RC 造校舎, 教育改革, 耐震補強, 開かれた学校, 耐用命数, 多目的スペース, 改築・改修シス テム
\end{abstract}

\section{1. まえがき}

昭和 30 年代から始まった戦後の $\mathrm{RC}$ 造校舎の建設 は, 約 40 年間に, 公立小中学校において延べ面積で 9 割以上の校舎が $\mathrm{RC}$ 造化される段階にまで進んだ。す でに，初期に建設された校舎には，老朽化を迎えるもの が多くなりつつあるが, その膨大なストックを今後どの ようにリモデルするかは, これからの学校建築分野の最 大の課題のひとつになると考えられる。リモデルには, わが国においても，この 10 年間大きく唱えられるよう になってきている教育の変革への対応が, 計画的課題之 して大きくなとりあげられることになろう。また，それ を実現できる好機と考えることが大事である。安全, 耐 震, 防災等の観点から, 改修すべきか, 改築にふみきる かの判断や, 改修のレベルと具体的な方法等, リモデル の構造的課題も多く数えられる. 以下の小論は, $\mathrm{RC}$ 造 校舎のリモデルを, 全国的な規模で取り組む必要のある 課題としてとらえ, 計画面, 構造面からの問題提起を行 うものである。なお,ここではおもに小・中学校校舎を 事例にとりあげて述べている。

\section{2. $\mathrm{RC}$ 造校舎の概要}

\section{1 戦後の $\mathrm{RC}$ 造校舎}

全国の公立小中学校の構造別の保有面積の年次推移を みると (図-1), 昭和 30 年代には大半の校舎が木造で, $\mathrm{RC}$ 造校舎は 300 万 $\mathrm{m}^{2}$ と全体の 1 割にも満たない状況 だった。もちろんこのなかには大正から昭和初期に建設 されたいわゆる戦前の鉄筋校舎が含まれている。しか

\footnotetext{
* 1 ながくら・やすひこ／共立女子大学教授 総合文化研究 所

＊2 たなか・れいじ/東北工業大学教授 建築学科(正会員)
}

し, ベビーブームや社会増などによる急増対策で建設量 が飛躍的に伸びていくなかで，木材の合理的使用および 学校建築の不燃化という当時の大きな掛け声により, ま た, RC 造が木造や鉄骨造の補助単価よりも高い単価 ${ }^{11}$ で定められていたことなども作用して， RC 造化が急速 に進んだ。

国立学校では大正 4 年の東京大学の化学教室の建物, 公立では大正 9 年の横浜市寿小学校や神戸の須佐小学校 が最初の例といわれているが，この時期の RC 造校舎 には名建築に数えられるものもあった。間取りは後述す る木造校舎のプランを踏襲していて変わらないが，3階 建て, 金属サッシ, 中央暖房, 内外に装飾付き, 都心で は小公園を隣接させ一体とした計画をするなど，今日で も新しさを感じさせる好例もある。しかし，この戦前の $\mathrm{RC}$ 造校舎も現在建替えが進み, 残っている小学校は数 10 校という状況になった。したがって, 現在公立小中 学校校舎の保有面積の約 9 割以上を占めることになった $\mathrm{RC}$ 造校舎はほとんどが戦後の物である。

そしていま，多数派となったこの鉄筋校舎は，昭和 25 年に作られた『RC 造校舎の標準設計』(図一2)によっ

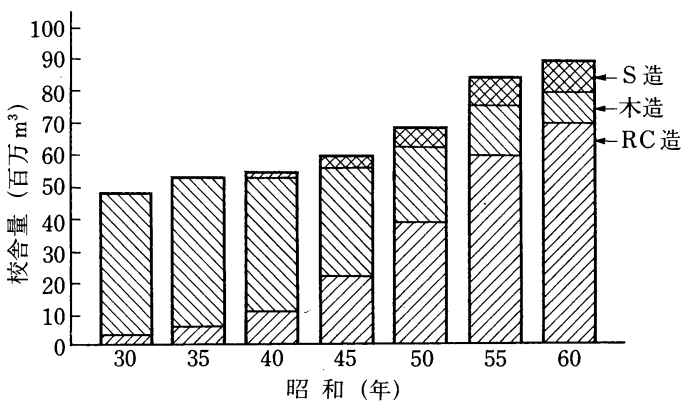

図-1 全国公立小中学校構造別校舎量の推移 

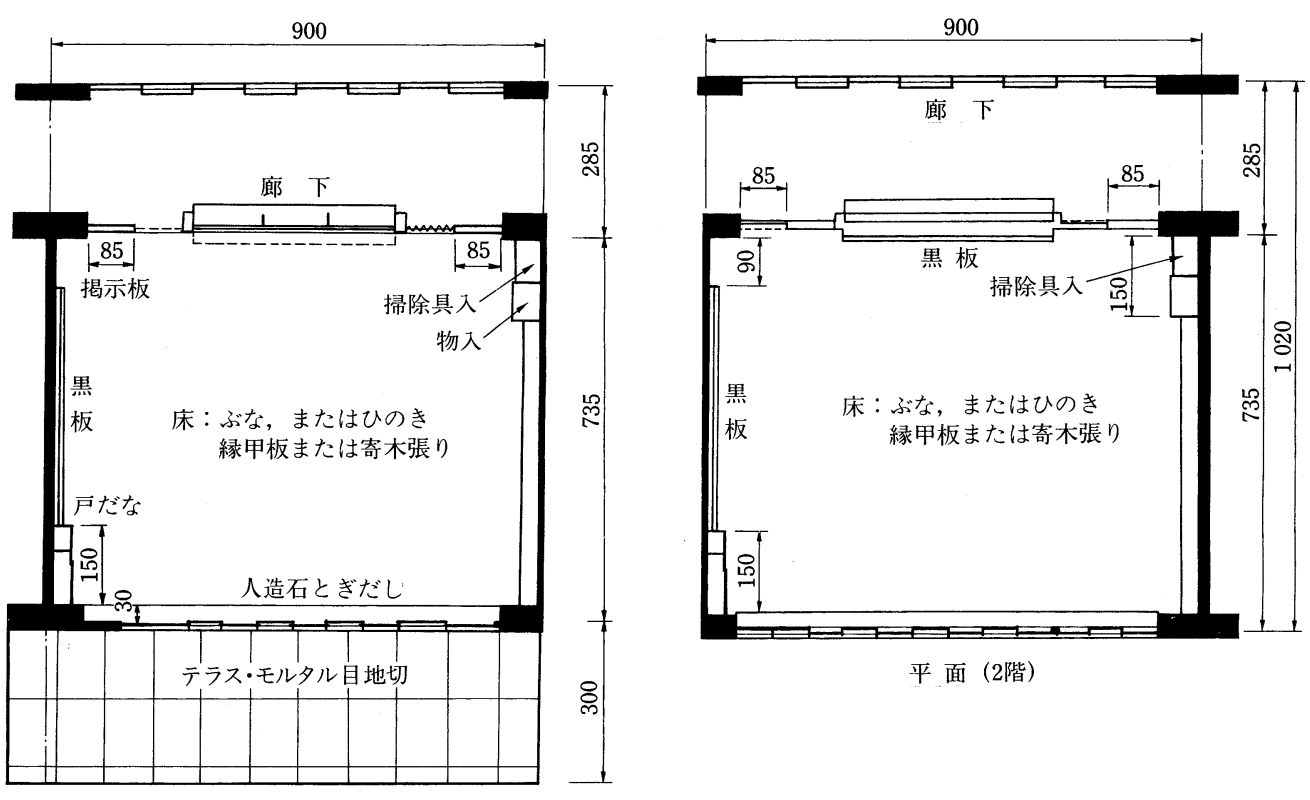

図-2 $\mathrm{RC}$ 造校舎の標準設計平面

て計画・建設されているのだが，この内容は，木造校舎 のルーツである明治 27 年に制定された『学校建築図説 明及び設計大要』を $\mathrm{RC}$ 造校舎向きに改訂したもので あり, したがって, 明治からの学校建築の流れはそのま
ま木造から $\mathrm{RC}$ 造に引き継がれたのである。「4間 $\times 5$ 間」が $\lceil 7 \mathrm{~m} \times 9 \mathrm{~m} 」$ の教室に, そして, 片側廊下型の 配置, という流れは変わらずに続き, 画一的, 定型的な 学校建築の全国的状況を作り上げる基になった。教室形

\section{Remodel for Postwar School Building}

By Yasuhiko Nagakura and Reiji Tanaka

Concrete Journal, Vol. 31, No. 9, pp. 5〜17, Sept. 1993

Synopsis It has already been forty years since the first postwar reinforced concrete school buildings were built in Japan. Over ninety percent of these buildings have the same balcony type structure, which have been criticized for their boring (non-characteristic) plain-site and block-plan, as well as functional problems that come from repeated "BARADATE". (Baradate refers to a practice of site planning of a new building that continuously adds to existing buildings based solely on space demand, without considering a more rational longer-term plan for expanding the use of the space.) For the last ten years uniformity in the Japanese educational system has been gradually changing to a more diverse system that characterizes the several aspects of Japanese educational revolution. As a part of it, site planning of school buildings needs to be improved. Earthquakes in the past have also shown the structural problems of postwar reinforced concrete school buildings need to be addressed. This paper covers these issues and discusses the necessity to create a "reconstruction system for postwar reinforced concrete school buildings" that is expected to take the next several decades to complete. This paper proposes its method in terms of both the theory of planning and design and also of structural design for seismic safety. At the end of the paper, we discuss the outstanding issues that need to be studied.

Keywords : postwar reinforced concrete school building, educational innovation, reinforcing for seismic safety, open school, durable years, multi-purpose space, reconstruction system 


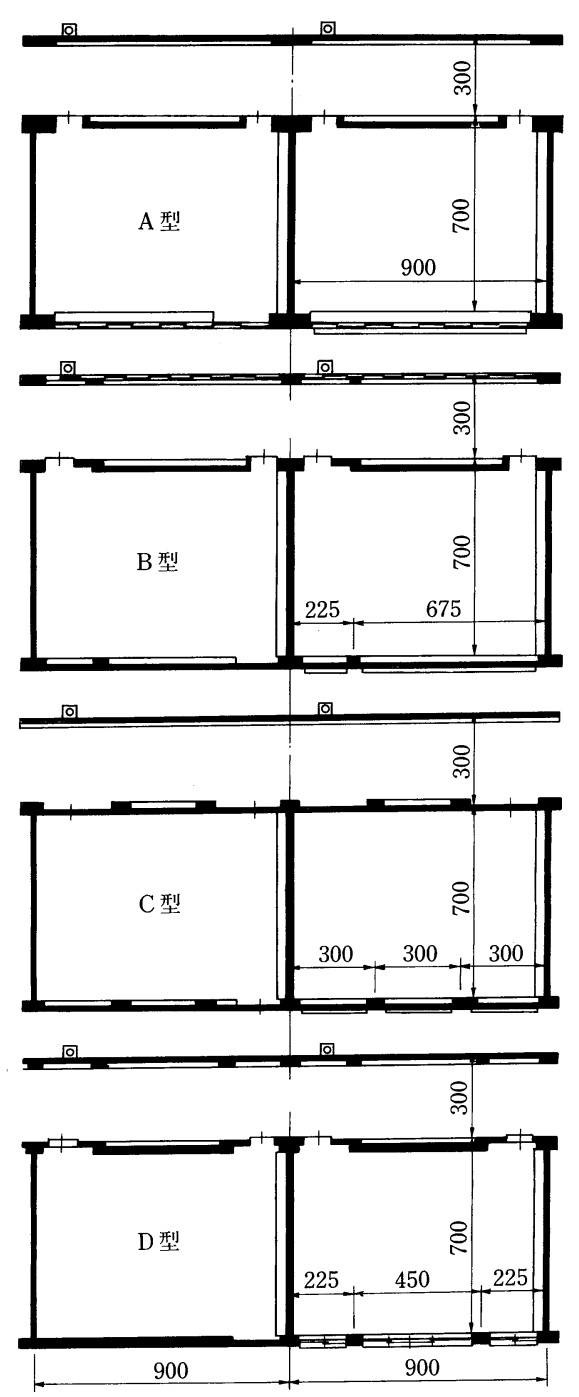

図-3 RC 造校舎の標準設計のタイプ

の標準設計は図-3に示されているように 4 種類が提案 され，それぞれ構造設計と積算を行って得失が示され た。

しかし，その後全国に多用されることになったのは， ご存じの「2 スパン」の教室である。この形式が全体の 室割をするのに使いよかったという結果によってである が，現在 9 割以上の教室がこのタイプといえると思う。 その後, 採光や照明, 色彩, 天井張り, 黒板, 暖房等の 工夫・改善により，教室の室内環境は格段に向上し，全 国津々浦々まで一定のレベルの学校を建設しつくしたと いう実績は，十二分に評価することができよう。しか し, 片側廊下型一辺倒の配置計画は, 学校種別にかかわ らず，学校規模を問わず，どの地域・地方でも，採用さ れ続け，学校建築の画一的・定型的なあり方の主因をな
すことになった。

\section{2 画一的 $\mathrm{RC}$ 造校舎の学校建築計画の基礎 - 基本 の欠如}

最近, 東京の $\mathrm{S}$ 区の小中学校の校舎を詳しく調査す る機会があったが, 戦後の $\mathrm{RC}$ 造化を代表する自治体 事例の一つでもあり，この結果を少し引用してみる。こ の $\mathrm{S}$ 区には 96 校の公立小中学校があるが，昭和 31 年 度から RC 造校舎の建設が始まり, 約 25 年間で長く続 いた不燃化の仕事はほぼ終了している。プランの一例を 図-4に示したが，いずれの学校もこのような一棟また は2 3 棟の片側廊下型であることは言うまでもない。

$\mathrm{RC}$ 造校舎は公立学校の場合, その時々の学校規模に 対して定められている資格面積と，その時点で保有する 面積の差分が国庫補助されるシステムで建設されてき

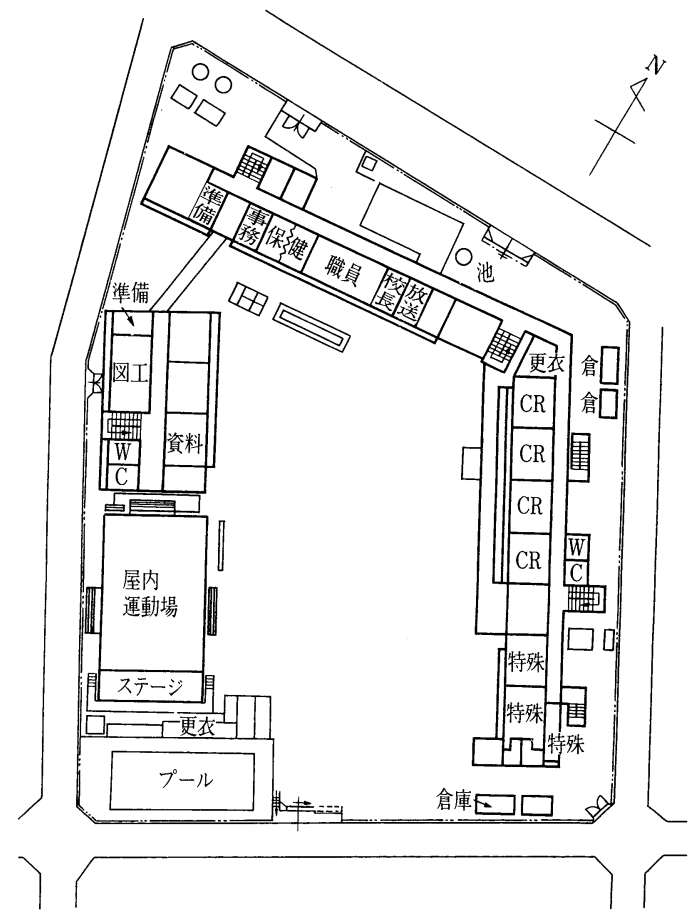

図-4 $\quad \mathrm{S}$ 区の小学校の配置

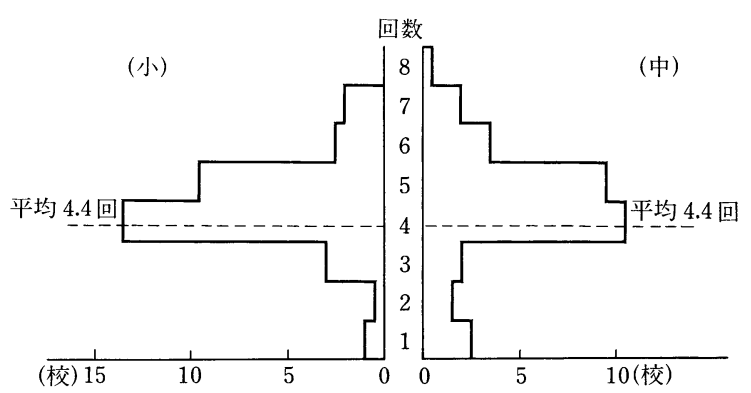

図 -5 分割建設回数 (1000 $\mathrm{m}^{2}$ 以上の校舎) 
た。したがってクラスが増える時代・時期に何教室かず つ建てて，いまの全体ができたという例が多く，これを 「バラ建ち」というのだが，この特徵を S 区の例でみて みよう。図-5に, $\mathrm{S}$ 区の小・中 96 校の学校ごとに, 全 面積のなかで分割建設された校舎面積が $1000 \mathrm{~m}^{2}$ 以上 の場合だけの回数をとり, その回数別の学校数を示し た。小・中とも, 平均 4.4 回の分割建設回数で, 最高は 8 回にわたって建設を経験した学校もある。

この分割建設で, 既存の木造校舎の RC 造化が始め られてから（新設校の場合もあるが，いずれも第 1 回の 分割建設時点), 直近の $\mathrm{RC}$ 造校舎の分割建設が行われ たときまでの期間別に学校数を示したのが図-6で, 最 近の建設校は短い期間で建設を終了しているのに反し, 古い学校はこの期間の長いものが多く, 小学校で 25 年, 中学校で 30 年にわたるものがある。

この長期間にわたるバラ建ちは, 今の $\mathrm{RC}$ 造校舎の 持つ問題のいくつかとつながってくる。本来, 画一的な 配置であるがゆえに, 敷地への適合や土地の有効利用等 が悪くなることと別に，全体計画を持たないままにバラ 建ちをした結果の問題校もたくさんある。また，その配 置のなかで室の位置や, 室相互の配置関係が崩れてしま うことは大変多い。S 区の例でこれを調べるため, その 過程は省略するが, 学校建築の現況に対し, 周辺環境, 学校環境, 校地利用, 建物配置, ブロックプラン, 体育 館, プールの 7 項目について, 学校建築計画の基礎・基 本と考えられる 40 の評価項目を設定し，96 校を関係者 で評価する研究を進めた。その結果の一部であるが, 項 目の評価を点数表示し, 96 校の相対評価を示す意味で 偏差値表示をしてみたが, このなかから校地利用, 建物

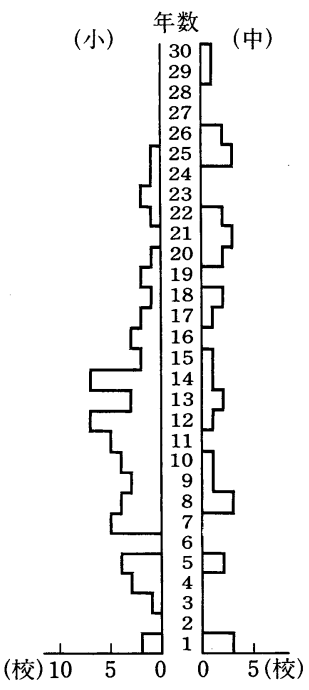

図-6 建設期間 (1000 $\mathrm{m}^{2}$ 以上の校舎 $)$
配置, ブロックプランの大項目についての偏差值の低い 校数を表 -1 に示した。

評価のスケールと対応して検討してみると，いずれの 項目についても約 3 割ある偏差值 45 以下の学校は, 建 筑計画的な意味において問題がある学校であり, それら はバラ建ちとの相関が高いのである。このような結果に 照らしてみると, 全体を一度に改築する整備を行う必要 があるということ, さらに, これからの新筑・改築は, 全体計画を必ず立て，できるだけいっぺんに建設を行う ことを基本とすること, さらには，全国の小・中・高等 学校, 約 4 万校のストックのうち, 建築計画の基礎・基 本に大きく欠ける校舎をその意味で改築または大規模に 改修する必要性の大きいことである。

\section{3 画一的な校舎と画一的な教育システム}

さて, 校舎の画一性は, 中身すなわちこれまでの教育 の画一性と一体になってきたという点が大きい。1クラ ス, 1 時間, 1 人の担任, 教科の授業という教育システ ムの骨格は, 小・中・高等学校を通じて, 今日まで変わ らないできているが，この近代的教育システムの基盤で ある一斉授業の形態は，そのクラスの子供たちの進度は 授業開始前で皆同じレベルにあり，すべての子供がその 授業を受けることがちょうどよいと思っており，授業が 終わると全員その知識を身につけることになるという前 提に立つシステムである。

こうした教育システムは, 明治の初めから工業化時代 の発展過程を通じて, 効果的なシステムとして機能し, 等質で質の高い製品を大量に作りだすことが目標の工業 化時代には，国民全体の教育水準をあげることのできる この教育システムはきわめて有効であった。そして, 45 人の一斉授業に対して, 黒板, 教壇, 左側採光の, $「 4$ 間 $\times 5$ 間」の定型教室は適切な形状で，どのクラスの一斉 授業も均質に行えることを保障するためには，片側廊下 型による教室の羅列が，これも大変適切であったといえ よう。一斉授業のシステムが画一的であったから, 学校 建筑も画一的になり，画一的であることが当然であった のである。

表-1 S 区の小中学校の計画面評定例

\begin{tabular}{|c|c|c|c|c|c|c|}
\hline & \multicolumn{6}{|c|}{ 評 価の偏差值別 校 数 } \\
\hline & 小 & 学 & 校 & 中 & 学 & 校 \\
\hline & 40 以上 & $40 \sim 45$ & $45 \sim$ & 40 以下 & $40 \sim 45$ & $45 \sim$ \\
\hline 校 地 計 画 & 11 & 7 & 46 & 6 & 4 & 22 \\
\hline 配 置 計 画 & 10 & 10 & 44 & 3 & 10 & 19 \\
\hline $\begin{array}{l}\text { ブロックプラン } \\
\text { (室 配 置) }\end{array}$ & 8 & 15 & 41 & 5 & 3 & 24 \\
\hline
\end{tabular}




\section{3. 新しい学校建築の必要性}

\section{1 画一化から多様化へ}

工業化時代から情報化時代への幕開けになった昭和 40 年代は, 情報の量, 伝達の手段・速度ともに, 飛躍 的に増加していく時代となった。小学校でも一年間の授 業時間の約 1000 コマは昔と変わらないが, このなかで 教える情報量は飛躍的に増加する。学校以外から情報を 得る手段も多くなるということもあり, 個々の子供の学 習に関する興味, 関心, 特性と, 授業の状況が合わない 率も高くなる。その結果の, 落ちこぼれ，あるいは学習 を抑えこまれている子供たちの増加は，学校ぎらい，校 内暴力, いじめ等の社会的問題を学校のなかにつくりだ す一因になっているという指摘もあって当然であろう。

情報化時代の進展によって, 一人ひとりの子供の発達 を望む教育の基本が，一斉に教える教育システムでは次 第に果たせなくなるという事態の到来ではないだろう か。一人ひとりの子供の個性を尊重し，これを伸ばすと いう教育の基本に帰るためには, “教える” システムに 対して“学ぶ ことをシステムにとりこんでいくこと, 一定のことを教えることを目標とするだけでなく，自主 的・自発的に行動していく生き方を身につけさせること が，教育の方針にならなければならなくなったのであ る。

画一化から多様化をめざすこのような目標設定は，す でに中央教育審議会の昭和 47 年当時の答申のなかにも うたわれており, 50 年代の教育課程の改定における選 択性の導入 (高校) や, ゆとりの時間の創設等は, その 具体化である。画一的・定型的であった教育施設・環境 の多様化への道もまた，定着しなくてはならない。

\section{2 多様な学習活動に対応できる学校建築}

このような視点から, 新しい学習空間は, 一人ひとり の子供の学習意欲に適合した状況が作りだせる「学ぶシ ステム」にも十分対応できることが必要となった。その システムには, 学習の進度や課題決定が自由になった り，選択できる方法など，さらに教科・科目も，いわゆ る合科や総合といわれる弾力化されたわく組を取り入れ るなどの工夫が必要である。個別の学習が展開する時間 は, 学習場所も子供たちそれぞれが, 学校じゅうから適 切な場所を選ぶことになってよく、このようなことか ら, 学校のなかすべてが教育のメディアであるという, 新しい学校建築の概念の一つが生まれてくる。

こういう学習活動のためには, 待ち受けるメディア が，子供たちの周辺に日常的に配置・配備されるととも に, 学校のいろいろな学習空間が, 相互に見わたせると いうことが重要になり, 空間の連続性が新しい学校建築 によっても大事な概念の一つになってくる。多様な学習
方法が展開されるなかで, クラス, 一人, 同一の進度の 子供たち, 同一の課題を選択する子供たちなど, 学習集 団の大きさが変化し, それに弾力的に対応できるスペー スをもつことが大事となり，しかも，ある時間の一斉授 業ののち, すぐに個別の学習形態に転換するというよう な場合を考えると，転換が速くできることも条件に含ま れる。

一斉授業では，黒板やロッカーへの行き来程度はあっ ても，自分の机にすわっている静止型が原則である。し かし, 個別化, 個性化を求める多様な学習活動では, 自 発的・自主的に学習が進行していくなかで，一人ひとり の子供たちの行動に動きがあることが基本となる。プロ グラムされた教材を順にとりにいき，各種のコーナーを 行き来し，ときに教師に相談にいき，また，みんなで集 まるという場面もある。こうした動きのための余裕のス ペース（スペース全体で小学校の場合 $3 \sim 4 \mathrm{~m}^{2} /$ 人必 要)，全体に室内音を静かにするための仕上げ（吸音天 井やじゅうたん敷など）等の建築的配慮が必要になって こよう。

\section{3 「生活の場」としての学校環境づくり}

画一的な学校建築では, 教える側が, 教えるために必 要とするだけの施設, 設備を整備することが目標であ り，それで十分ということだった。しかし，「学習者の 側から組み立てる学ぶ場」としての学校では, そこに子 供たちが一日，そして一年間いるということにおいて必 要とする機能を，できるだけ満足しうる施設・設備を用 意することが目標に加わってくる。学校は, 子供の生活 環境施設になるということであり,「生活の場」とは, そのことを指しているのである。一人ひとりの子供に とって, また, 子供たちどうし, あるいは先生との間に 起こる“語る, 遊ぶ, 休む, 作業する, 食事する”など の人間的諸活動は，ここでとりあげるべき大事な機能で あり，そのためのロビーやホール，ラウンジやコモンス ペース, 広場や食堂, プレイスペース等が, 学校の空間 の構成要素として位置付けられ, それらを教室よりも重 視するくらいの考え方をもって環境づくりを行うことが 大切になる。

さらに「生活の場」づくりには，こうした機能への対 応のほかに, ゆったりしたスペース, 広い空間, 変化・ 開放感，あるいはどっしりした感じなどの雲囲気をも つ空間構成，十分な緑，自然を生かす配置など，これま での学校建築ではまったくと言ってよいほど省みること のなかった，感性にうったえる建築・環境とすること が, とくに必要になってくる。一人ひとりの学習者の側 に立つ学習空間づくりの概念は, 一つひとつの学校を, 個性的にすることにつながるわけで，そこにおいて，は じめて学校建築の文化性, 地方性が息づくことになると 
いえよう。

\section{4 地域における学習者の「生涯学習の場」となる 学校}

生涯学習という言葉は, この数年来すっかり定着して きたけれど, このことと学校教育, 社会教育とは本来異 なったとらえ方をすべき点を初めに確認しておきたい。 社会教育は，あくまで教育をする側からの体系づけで あって, 一方, 人間は生涯にわたって勉強するもの（し たいもの）であるという概念のもとに, 学習者の側に 立って教育システムや, 学習環境・メディアの整備をし ていくこと, それが生涯学習社会の構築である。とすれ ばこのことは子供たち一人ひとりに応じうる教育シス テムを目指すこれからの学校と通じ合うことになる。

今までの教育目的施設としての学校は, 空いている施 設を貸すことはあっても，地域に対し閉じられているの が当たり前の施設だった。しかし, 学校そのものが変わ ることによって, 地域・周辺の住民・学習者もまた, 学 習という目標において子供たちと同じ立場に立ち, 同じ 機能を享受する存在になることは当然のことである。こ ういう概念によって, 学校の機能とともに, 施設もまた 放課後, 夜間, 休日に地域住民・学習者が利用すること への対応が, 新しい学校建築の計画の基本になってく る。

さらに, 生涯学習の体系において, 学校がより「開か れた場」となっていくためには, 学校施設における機能 のレベルアップとともに，これまでの学校に常備の機能 を超えて, 学習面における多機能化を図ることがとくに 期待されるのだが，このことは，子供たちの学習の多様 化を図るという本題に直接役立ち, つながることでもあ る。多機能化の実現には, 本来的に機能している施設や 本格的機能を備えた施設を, 学校に複合化する計画はと くに有効であり, 地域により, 立地に応じて積極的に検 討していくことを常に学校建築計画にとりあげることで ある。さらに, 学習活動に付随して起こる交流, 集会等 地域における人間的諸活動を支える機能・施設にまでこ の複合化を広げることは, 学習者の「生活の場」となる べき新しい学校建築の概念からいって当然の道である。 複合化は, それぞれの施設が統合・融合された空間の状 態に置かれること，つまり，そこに来る人が関連しあ い, 集まる人が共在しあい, お互いが学習について刺激 しあうことの可能なように, 学校および施設が, 有機的 で連続性をもつ空間で構成される必要がある。

\section{5 コンピュータの導入}

学校にコンピュータの導入というと, いずれもコン ピュータの教育用に, コンピュータを何台もずらりと並 ベたコンピュータ教室を作るというのが一般的になるの だが，こうした行き方は，鍵のかけられた校舎の端の特
別教室の中にあるコンピュータを，一週間に一時間使う というような限定された使い方につながってしまう。 もっと日常の利用, すなわち, デモやシミュレーショ ン, CAI, データバンク, 管理・運営に, 学校の種類や 規模に応じて利用するという前提に立ち，コンピュータ が学校のいろいろな場所に入り込む姿を描くべきであ り，それはまた，個別化・個性化を目標とした学習シス テムの展開を全面的に支援することにつながってくる。

この場合, 新しい学校建築は, それに対応しやすいこ とはいうまでもない。オープンスペースのなかのワーク ステーションや, コーナーに, また, 教師コーナーや教 材センター, 校務センター等に, 分散配置することは容 易といえよう。分散配置はネットワーク化に対応し, ひ とつの学校のなかだけでなく, 地域や地方全体のなかで の活用に結びつく点も課題となってくる。さらに, 健康 を維持できる快啇な空間を構成するための制御，そのた めの省エネルギー, 省資源への制御にも, 新しい学校建 筑において活用すべき点は少なくない。また，コン ピュータ等新教育機器の導入にも関連して, オープンス ペースを中心に, フロア構造, 十分な電源, VDT 環境 としての空, 照明, 家具, 冷暖房などの建築・設備の基 盤整備を, 学校建築の質的向上の分野に位置づけること も必要である。

\section{6 新しい学校建築の事例}

富山県の福光町に, 壁を全部可動にした学習スペース を持つ公立小学校が出現したのは昭和 51 年で, このと きから日本において新しい学校建築の具体的な事例が始 まったといってよいと思う。それから 10 年経った昭和 61 年の調查では, 全国 3 万 4000 校の公立小・中学校 のなかで, これまでの教室とは違う学習空間を持つ学校 は 2000 校数えられる結果になった。その後も建てられ たものもあるので，そうした例も加えて新しい方向の学 校建築は, 現在では全国で約 3000 校ということになっ てきた。

文部省では公立小・中学校に対し, 通常の面積補助に 加えて, 多目的スペースの補助を数年前から行っている が, この多目的スペースは, すでに記してきた学校の オープンスペースと同義のことであり, そのほか, 木で 建物を仕上げることや，よい環境を創造するための補助 等とともに, これらは, 新しい学校建築を展開していく ことに大きな効果を上げつつある。また，これまで述べ てきたような概念を約 100 の項目に具体化した「教育方 法等の多様化に対応する教育施設のあり方」という提言 を昭和 63 年に 3 年かけてまとめたのを皮切りに, 平成 2 年には「文教施設のインテリジェント化について」を発 表し, 生涯学習社会における学習環境の整備についての 提言を行った。さらに, 平成 4,5 年には, これまで 
あった $\mathrm{RC}$ 造校舎の設計指針（明治以来の基準を昭和 42 年 $R C$ 造校舎向けに学校施設指導要領として制定） の全面改訂を行い, 前述のような新しい学校建築作りの 考え方を『学校施設整備指針』の小学校編, 中学校編, 幼稚園編にそれぞれまとめ提示している。

\section{4. リモデルのための計画的課題}

\section{1 画一的な $\mathrm{RC}$ 造校舎の改築・改修計画}

$\mathrm{RC}$ 造校舎は大体が昭和 30 年代からのバラ建ちであ るので，棟やその部分によって年代が違うことは普通だ が，いずれにせよ古い事例はすでに 40 年近い年をとっ ている。ということは，極言すれば全国 4 万校の小・中 高等学校の $\mathrm{RC}$ 造校舎は, これからの何十年間に, い ずれも $\mathrm{RC}$ 造建築の建直しに達するということであ る。条件の悪い時代の $\mathrm{RC}$ 造工事とか, 以前はよい仕 上げが使えなかったとかいうことが，この年数の縮小に 拍車をかけようし，したがって，これからの 10 年は, 校舎の改築課題の準備・実施に真剣に取り組む時期に なったといえよう。そして，この全部の改築を短い期間 にいっぺんに行うことの無理なところは多いだろうし， したがって前倒しをして早めに手を着けていく課題も生 じると思う。と同時に，これから長い期間を要するこの 改筑計画において, 後回しになる学校には本格的な改修 を行う必要があり，それにはごの時点で改筑・改修をす るかの合理的判断とともに，その結果として，その町全 体の改築計画の一貫として大規模改修をとらえることに なろう。これからの改築・改修は, かつての急增, 社会 増対応の RC 造校舎建設に劣ら㰠事業だが, 画一化 から多様化を図る好機ととらえることができるし，それ を実現することが大事である。

\section{2 改勧・改修の段階}

改築・改修にはいろいろな段階が考えられるが, 既存 校舎の撤去があるか, 新增築があるか, 既存校舎の大規 模な改造があるかどうか，そして，既存校舎をそのまま 使う部分が残る場合もあり，これらの組合せということ になる (表-2)。ここでの改造は, 主要な構造部分を残 して行うものを指すが, 一方で, 主要構造部分を補強す るという状況が広範囲にあり得るから, この補強と改造 が同時に計画されるケースもある。増築の可能性は, 公 立小・中学校において国庫補助を受けることを条件とす るかぎりでは，児童生徒の減少するいまの時期にはケー スとしては少ないであろう。しかし, 前述した計画的課 題を目標とする改筑・改造への対応には増築も含めて考 えることが望ましい場合が多い。

さて, 画一的な $\mathrm{RC}$ 造校舎全国 4 万校のストックに 対する改造・改築の課題を改めて整理してみると次のよ うになろう。
表-2 改築・改修の段階

\begin{tabular}{|c|c|c|c|c|c|c|}
\hline & 既存校舎 & 新築 & 増築 & 改造 & 残置 & 通 \\
\hline A & 全面撤去 & 0 & - & - & - & 全面改築 \\
\hline B & $\begin{array}{c}\text { 一部撤去 } \\
\text { " }\end{array}$ & $\begin{array}{l}- \\
- \\
-\end{array}$ & $\begin{array}{l}0 \\
0 \\
0\end{array}$ & - & $\begin{array}{l}- \\
0 \\
0\end{array}$ & $\begin{array}{c}\text { 増築改造 } \\
" \prime\end{array}$ \\
\hline $\mathrm{C}$ & 一部撤去 & $\begin{array}{l}- \\
-\end{array}$ & - & & - & 改築大規模改造 \\
\hline $\mathrm{D}$ & 撤去せず & $\begin{array}{l}- \\
- \\
-\end{array}$ & $\begin{array}{l}0 \\
0 \\
0\end{array}$ & - & $\begin{array}{l}- \\
0 \\
0\end{array}$ & 増築改造 \\
\hline $\mathrm{E}$ & 撤去せず & $\begin{array}{l}- \\
-\end{array}$ & $\begin{array}{l}- \\
-\end{array}$ & & - & 大規模改造 \\
\hline
\end{tabular}

注） はは構造補強のあるときも含む
A : 直接的対応
1）学校建築計画の基礎・基本に ついての大きい欠陷の改善
2) 多様化を求める新しい教育環 境創造への対応
3) $\mathrm{RC}$ 造の主要構造部の耐力低 下等への対応（耐震・老朽 等)
4）建物老朽への対応（仕上げ, 造作, 設借等)
$\mathrm{B}$ : 間接的対応 1 1) 学校規模の検討（学校の統廃 合, 適正規模論)
2) 校地の有効利用
3）余裕教室の活用
4) 町なみ, 景観への寄与
$\mathrm{C}:$ 実施上の課 題
1) 工事中の学校運営への対応
2）建築後改定された法令・基準 への対応
3) 財政等をめぐる課題への対 応

直接的対応は, 改築・改修の主因である。学校建築計 画の観点からみて A-1) の基礎・基本に欠ける学校校舎 の多いことは前述したが, これをいまこそ改善するとい う視点が重要である。基礎・基本の内容についてはここ では言及し得ないが，とくに大事な配置計画とブロック プランに関する計画性については別揭の文献 2) を参照 していただきたい。そして, 計画的課題としてとくにと りあげるべきが, A-2) の新しい教育環境への対応であ り, これについての課題の内容はすでに詳述したとおり である。

全面改築ならば，新築と同様これらの計画的課題に取 り組むことは容易であろう。また, 逆にこの計画的課題 こそ優先するという認識をもって, 改築・改修を行うの が学校建築の質的整備の本来の目標である。新築の場合 
に比して C-1) の工事中の対応が大きな条件，制約にな るから, 具体的に慎重な計画を進める必要がある。直接 的な対応は，B-1)〜5)に掲げる課題ととくに関連する 場合があると同時に，それらの具体的な状況に取り組む ことが改筑・改修の契機になるという場合も考えられ る。

A-3) および A-4) の構造的対応面については，5 章 に詳しく述べられるが，C-2 にかかわる昭和 40 年代か ら 50 年代にかけての法令の構造基準改定に抵触するこ とになった $\mathrm{RC}$ 造校舎について, 安全性のチェック, 改造時の構造補強を検討する場合, その対応に対し, 室 内環境への影響や外観等の計画面での十分な検討が必要 である。

\section{3 建物の老朽化について}

昭和 30 年 40 年代の $\mathrm{RC}$ 造校舎は，種類が少なかっ たこともあるが，仕上げ材料のなかで質のよい物は使わ れていない。外壁仕上げ, 屋根仕上げ等は, コストが最 低に属する材料が使われている種類の建物だった。ま た, 内部仕上げも同様のレベルにあり，こうした材料使 用の状況は, 一定の補助の基準の関係も背景にあって, 年代的に，地域的に共通の傾向を有している。このよう なことから, 後述するような, 経過年数を共通の仕上げ の老朽化指標とすることが可能になるともいえよう。

学校校舎の経過年数については前述したようなバラ建 ちの問題がある。すなわち, 間をおく何度かの工事でで きている 1 ブロックの棟の全体や，そのような棟をいく つも持つ学校全体の経過年数の見方であるが，いまは次 の 2 つが利用されている。

1）同一年度の工事範囲ごとに，その範囲の床面積に その経過年数を乗じ，その合計をその棟あるいは学 校全体の床面積で除した, 棟の平均経過年数あるい は学校の平均経過年数

2）最初にかなりの面積の工事を行った年，すなわち $\mathrm{RC}$ 造校舎の改築初年と目される年からの校舎経過 年数。合理性には欠けるが，同一設置者のなかで順 番を論ずる場合にはこのほうがよいという意見もあ る。

ここで前掲した $\mathrm{S}$ 区における詳細な研究結果から3) 該当する分析結果を一部引用してみる。まず， $\mathrm{S}$ 区の 96 校の校舎平均経過年数 (図-7) をみると，これは全国的 にも共通の状況であるが，校舎の平均経過年数では 15 30 年という幅に分布している。ここで, 96 校の小 ・ 中学校のうち, 棟の簡易耐力度を求めた例について, その棟の平均経過年数との関係を図-8に示したが，そ れらに相関がみられること，そして相関の異なるとみら れるデー夕群を 2 つに分けて回帰分析を行ってみると, 平均経過年数 30 年程度で簡易耐力度が 4000 点を切る

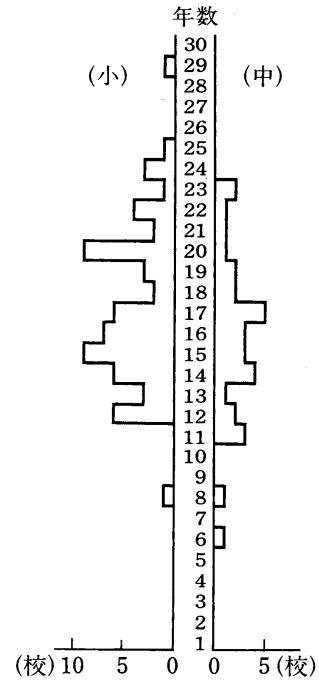

図-7 平均経過年数（校舎）（昭和 63 年）

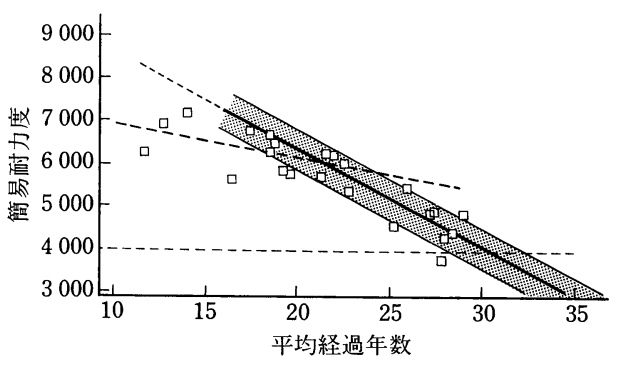

図-8 平均経過年数 20 年末満と 20 年以上の回帰直線

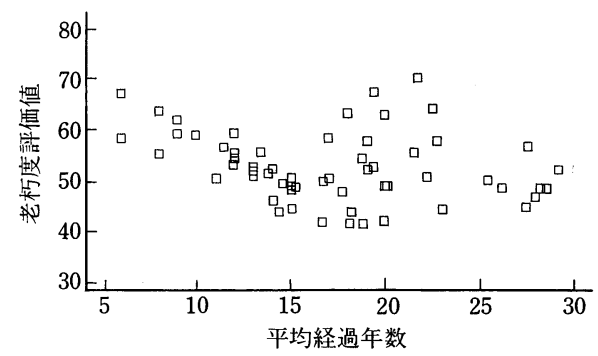

図-9 平均経過年数別内部老朽度

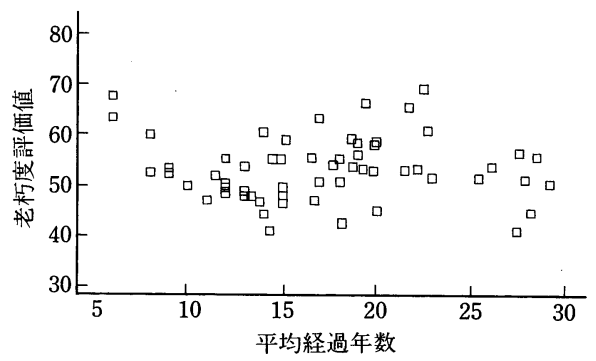

図-10 平均経過年数別外部老朽度 


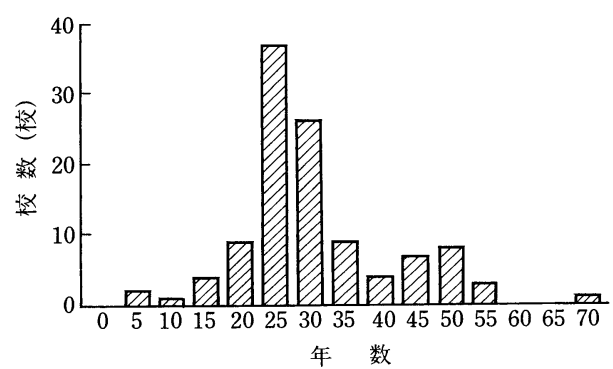

図-11 校舎の取壊し年数分布

という結果だった。

仕上げの老朽度として，修繥した場合の年度，耐震性 能, 屋根と外壁材料, 校舎内部仕上げ材料, 校舍全体の 5 つの要素における評価項目を目視によって採点し，そ の総合結果を老朽度評価值 ${ }^{4)}$ として外部, 内部別に棟の 平均経過年数との関係を示したものが図-9,10であ る。やはり年数に相関して老朽度評価值は低くなるこ と, 15 年（国庫補助の対象を改廃することが認められ ることになる期間）を経て上がる例は，大規模改修によ るものでそれにより仕上げ材料の改善が行われたことを 示している。一方, 昭和 62,63 年に国庫補助を受けて 建設を行った校舎, 屋内運動場に関する建設内容の調査 （対象 2283 校の $1 / 5$ 抽出）から ${ }^{5}$ ，この事業を $\mathrm{RC}$ 造の 既存校舎の取り壊しにより行った 107 例について取り壊 した既存校舎の平均経過年数別の例数を図-11 に示し た。7年で取り壊して改築した場合から, 長いほうは70 年使用した（戦前の $\mathrm{RC}$ 造）校舎がみられたが，平均 では 33.3 年という状況であった。東京における戦前の $\mathrm{RC}$ 造校舎の改築に対し, 50 年経過を改築着手の指標に 用いたということもあり, 改築か改修かの判断は大変に 難しい要件を含むのだが，ハード面についてはこれらの 経過年数の動向が参考になるのではないかと思う。

\section{4 改築・改修の順序}

次に一校の改築・改修の問題とともに, 多くの学校建 築を設置してきた自治体の既存 $\mathrm{RC}$ 造校舎について は，順番に改築・改修をしていくことになるであろう し，それを計画的に行うことが今後重要になる。その 際, 改築・改修の順序づけは, これまた社会的, 政治 的, そして教育上に多くの問題, 複雑な課題を抱えがち である。具体的な順序づけはいったん置くとして, 多数 の学校の改築・改修課題を一覧の表 ${ }^{6)}$ で示したのが図 -12 である。事例としては東京都の N 区の小学校 28 校 を掲げてある。

縦軸に校舎経過年数の古い学校順に下に向かって並べ てある。横軸は昭和から平成に向かっての経過年数であ る。昭和 31 年からおよそ 45 年までの 15 年間に 28 校の 学校が建設された。経過年数 40 年で改築着手という線

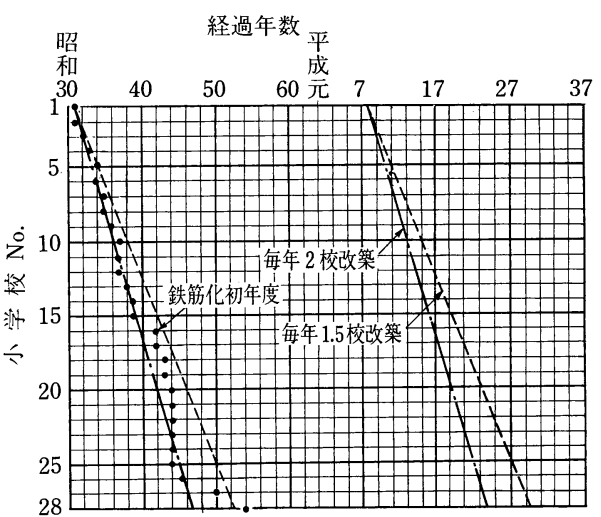

図-12 改築・改修の課題例

は私見としての一般的指標であるが，これとすると平成 7 年から毎年 2 校の改築事業をしなくてはならないこと になる。40 年代の RC 造校舎のグループの年度ずれ 之, 各校の平均経過年数を考慮すると 1.5 校/年という ラインも書ける。しかし, 順序どおりにいって全部の事 業が終わるのは平成 30 年を超える。後発の学校には老 朽化の改修が入らなくてはならないことになり, さら に, 先行する改築校の現代化が進むと, 単なる外部仕上 げの改修程度ではすまなくなることは当然で，前述のよ うな計画的課題に十分応えられる改修を間に挟むという 計画が必要になろう。つまり, 1.5 校/年の改築事業に加 えて, 毎年 1 校程度の十分な内容を持つ大規模改造事業 を行うことが必要になってくるというわけである。

\section{5 間接的対応の課題と関連する課題}

間接的な対応については, 改築・改修に検討されるこ とになる課題の意味と，それ自体が改築・改修の引き金 になる場合もあり，今後の計画論として十分検討する必 要があろう。関連する課題については, とくに工事中の 対応がきわめて大きい条件となり, 改築・改修計画その ものを左右する場合があり，その他の項目とともに十分 検討することになろう。紙数の関係がありこれらについ てはまた別の機会を待ちたい。

5. RC 造校舎のリモデルの構造的アプ ローチ

既存 $\mathrm{RC}$ 造校舎を実際に 1 4 章で述べてあるよう に，リモデルしようとすれば，当然のこととして構造的 検討も必要になる。そこで，ここではリモデルにあたっ て構造上配慮すべきことを簡略的に述べる。詳細につい ては参考文献を参照していただきたい。

\section{1 リモデルにあたっての構造の考え方}

既存 $\mathrm{RC}$ 造校舎をリモデルする要因としては, 前述 した計画的要因のほかに構造的要因（構造材料の老朽 
表-3 建物のリニューアル

\begin{tabular}{|c|c|c|c|c|}
\hline & & 耐震補強 & 改 & 改 \\
\hline 構 & 造 & Active & Passive & Active \\
\hline 計 & 画 & Passive & Active & Active \\
\hline
\end{tabular}

表-4 耐震補強とリモデルの検討フロー

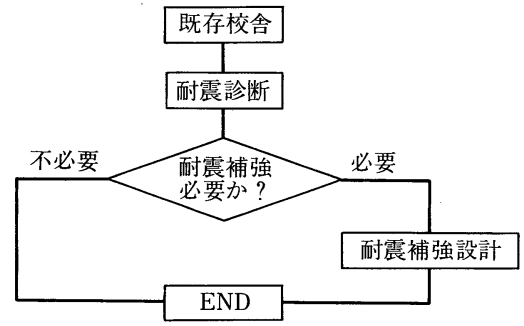

（a）耐震補強の構造検討フロー

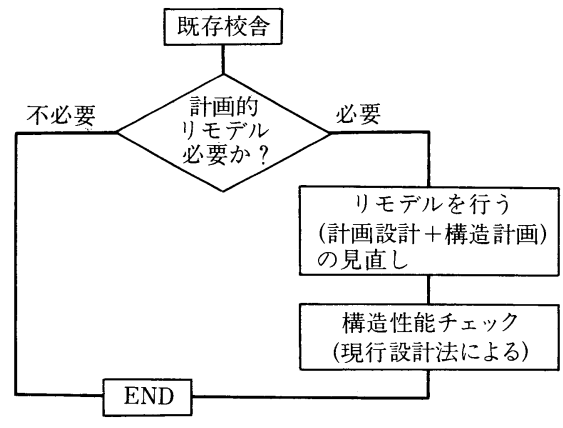

(b) リモデルの構造検討フロー

化，構造設計法の変化など）も考えられる。

学校建築を社会的変化に対応させることを考えた場 合, 計画的要因がリモデルの主たる理由で, 構造的要因 が主たる理由になることは少ないであろう。しかし，近 年, 学校建築においても構造的要因を主たる理由とした 耐震診断, 耐震補強なども行われているが（耐震診断， 耐震補強を行うにあたっては文献 1)，2）などを参考に するのがよ(), 通常, 耐震診断, 耐震補強では建物の 機能をできるだけ現状維持することを目標とする。

それに対し, リモデルの場合は計画的要因が主たるも のであるから, 建物の機能変化が可能であり, それに 伴って構造計画の見直しの自由度も大きくなるところ に, 耐震補強における構造計画の考え方とは明らかに異 なる。このような関係を岡田恒男博士 (東京大学生産技術 研究所 教授) は表 $-3^{3)}$ のように示している。すなわち, 耐震補強は構造が主体的であり, リモデルは構造之計画 の両者がともに主体的に行うものであるとしている。表 -4 (a), (b) に耐震補強とリモデルの場合の構造の検討 フローの相違を示しておく。

計画的なりモデルを構造への要求事項として分類する と，表-5 のようになる。すなわち，計画上リモデルを
表-5 リモデルによる構造への要求事項の分類

\begin{tabular}{l|ll}
\hline 床面積増設の有無 & \multicolumn{2}{|c}{ 構造への要求事項 } \\
\hline & A 1) & 既存構造要素を撤去しない \\
{$[\mathrm{A}]$ 増設しない場合 } & A 2) & 既存構造要素を撤去する \\
& A 3) & 構造要素の追加可能 \\
\hline & B 1) & 建物の上層に増設 \\
& B 2) & エキスパンションを設けないで \\
& & 増設 \\
& B $]$ 増設する場合 & エキスパンションを設けて増設 \\
\hline
\end{tabular}

床面積の増減のみからみると, 床面積を増設しない場合 （現状の床面積で機能変化の工夫をする）之増設する場 合の 2 種に大別される。それらに応じ, 構造的には表一 5 に示す A 1) A 3) および B 1)〜B 3) のような対応が 要求される。上記のほかに仕上げ材および設備機器など の老朽化から要求されるリモデルに対しても，構造上は 表-5の A 1)〜A 3) のいずれかで対応できるはずである。

表-5で, A 1) は構造要素の変動はないが, 現行設計 法への安全性の再検討が必要である。もし, 安全性が不 十分なときは耐震補強などの処置が必要となる。

A 2) は, 平面的に広いスペースを確保する場合は柱, 壁の撤去が要求されるし，立体的に広いスペースを確保 する場合にはおもに床，はりの撤去が要求される。さら に場合によっては柱, 壁などの撤去も必要になることも 考えられる。当然のこととして, この場合も現行設計法 に対する検討は必要である。一般に, 構造要素を撤去し た場合には, 撤去分の構造要素の追加が要求されるが, 学校建築のはり間方向は通常壁量が多いので, はり間方 向の耐震壁の撤去は耐震要素の追加が不必要な場合も考 えられる。構造部材の撤去の可能性については詳しくは 文献 4) で述べているので参考にしていただきたい。

A 3) は, 児童数の減少などにより余裕教室などが存 在し, それらの空間を構造要素の追加に利用できる場合 であるが, 余裕空間の計画的利用にあたっては構造計画 の要求も十分考慮のうえ計画する必要がある。構造的に はこれらの余裕スペースを利用することによって，単な る部材単位ごとの耐震補強による方法だけでなく, 骨組 単位あるいは建物全体の構造計画の見直しも可能であろ う。

B 1)〜B 3) の要求に対しては次のようなことが考え られる。

B 1) の既存校舎の上層に増設する場合であるが，将 来的な荷重増分を考慮していないものは, 基礎耐力上か ら考えて, 一般的に増設は不可能であろう。柱部材は通 常軸方向力に対しては余裕がある。增設荷重の増分を考 慮している場合でも, 現行設計法を満足しなければなら ず，相当な耐震補強が要求されることを考えれば，上層 に増設する方法は経済的負担の大きい方法といわざるを 
得ない。ただし，増設の付加荷重が小さく現行設計法を クリアーできれば可能なことはいうまでもない。この場 合でも, $\mathrm{R}$ 階はり部材耐力が付加荷重に対して安全であ るかを確認する必要がある。耐力不足の場合には補強な どの処置が必要である。

B 2) の平面的にエキスパンションを取らずに増設す る場合には, 当然, 既存の柱および基礎に増設の鉛直荷 重が付加されることになり, それらによって生ずる応力 に対する既存の柱および基礎の検討が必要となる。その 結果, 柱および基礎耐力が不足している場合は既存部材 を補強する方法も考えられるが, 既存校舎に隣接して柱 および基礎の増設をして対応することも可能である。も ちろん, 増設後は既存校舎を含めた現行設計法による総 合的な検討が必要である。エキスパンションを取らずに 増設する構造的メリットは, 増設スペースの計画がかな りの自由度で行え, 増設部分の構造計画を既存校舎の構 造も考慮のうえ相当大胆に行うことができるということ である。すなわち, 既存校舎が耐震的な問題などをかか えている場合でも, 計画と構造の両者をうまく調整し, リモデルを行えば, 既存校舎の構造的問題点をリモデル で処理できる可能性が高い。

B 3) の平面的にエキスパンションを取って増設する 場合には, 既存校舎への付加荷重はなく, 既存構造材へ の影響がないので, 増設は自由に行える。既存校舎に手 を加えたくない場合には，エキスパンションを取って増 設する方法がもっとも優れている。

\section{2 既存 RC 造校舎の構造上の特徵}

$\mathrm{RC}$ 造校舎のリモデルを行う場合, 既存校舎の構造の 特性を知っておくことは重要であろう。ここでは現在の $\mathrm{RC}$ 造校舎の構造上の特徽についてその概略を述べる。

\section{（1）柱および壁の配置}

既存校舎の柱および壁の配置は教室の大きさと密接な 関係にある。柱の配置形式は図-13 に示すように, A 型, B 型, $\mathrm{C}$ 型のものが多い5。 $\mathrm{A}$ 型はけた行方向が各 教室 1 スパンで, $\mathrm{B}$ 型は 2 スパン, $\mathrm{C}$ 型は 3 スパンで構 成されているのが特徴である。教室のはり間方向は通常 1 スパンで, 教室の大きさはけた行スパン 8 9 $\mathrm{m}$, はり 間方向 7 7.5 m のものが多い。各教室には隔壁がある ので, 構造上ははり間方向は壁量の多い建物となってい る。しかし, 隔壁がすべて耐震壁であるかは疑問で経済

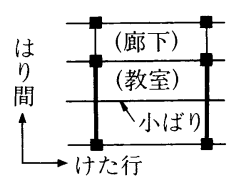

A 型

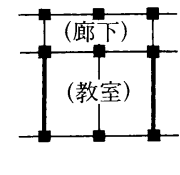

$\mathrm{B}$ 型

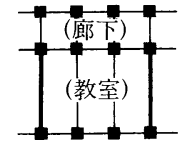

C 型
図-13 既存 RC 造校舎の柱および壁の配置
I 型 片側廊下式

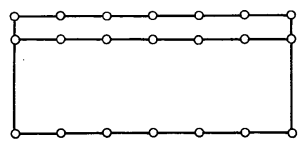

II 型 中廊下式

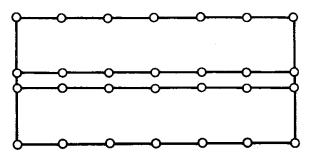

III型 一部中廊下式

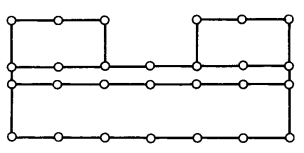

IV 型 1スパン型

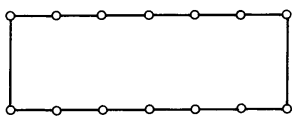

図-14 既存 RC 造校舎の平面形状

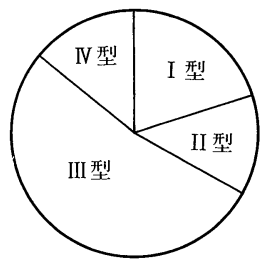

図-15 既存 RC 造校舎の平面 形状比率

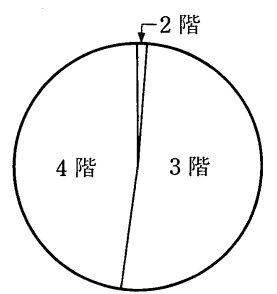

図-16 既存 RC 造校舎の階数 分布
上ブロック壁などを使用している場合も考えられるの で,リモデル時には事前調査が必要である。

けた行方向は校舎の機能面からオープンフレームで, 耐震壁の少ない純ラーメン骨組に近いものが多い。しか し, 図-14 に示すような中廊下式のものでは中廊下部分 に耐震壁が多少存在している例もある。

けた行方向で最も特徽的なことは，北側（廊下側）柱 のけた行方向が腰壁などにより可とう部分の短い短柱に なっている例が比較的多いことである。これら短柱は過 去の地震においてもせん断破壊などの被害を受けている 例が多数見られることから, リモデルの際には建物全体 の耐震性を考慮のうえ改善されるべきものであろう。

(2) 校舎の形状

既存校舎の一般的な形状，すなわち平面形状および階 数を仙台市における調査例をもとに述べる。図-146) は 仙台市内の小学校校舎の形状を分類して示したものであ る。 I 型〜 IV 型の 4 タイプに分類される。I 型は片廊下 式, II 型は中廊下式, III 型は一部中廊下式, IV 型は 1 ス パン型である。各形式の比率は図-15 のとおりで，林型 の一部中廊下式がほぼ $50 \%$ ともっとも多く，I 型 $(20$ $\%), I V$ 型 (15\%) が次に多い。校舎の階数は図-16に示 すようにほとんどが 3 階および 4 階で, 2 階は非常に少 ない。

( 3 ） 校舎の耐震性能

$\mathrm{RC}$ 造校舎の場合, 構造上もっとも問題となるのは耐 震性能であろう。既存校舎は図ー14に示したいずれの夕 
イプのものでも教室配置の関係上，はり間方向に耐震壁 が多く、けた行方向はオープンフレームになっているも のが多い。校舎の耐震性能は個々異なるが，一般的な性 状として, はり間方向がけた行方向に比へ耐震性能が大 きい。このことはリモデルする場合には，できればけた 行方向の耐震要素を追加できるような計画変更が望まし いことを意味している。既存校舎の耐震性能の特性は過 去の地震被害からもみることができる。昭和 53 年の宮 城県沖地震での仙台市内の校舎被害を調べた結果 ${ }^{6)}$ によ ると, 被害はけた行方向に集中しており, はり間方向の 被害はほとんどみられない。また, 4 階建てのほうが 3 階建てよりも被害が多いのも興味深い。

\section{3 構造のリモデルにかかわる規・基準の変遷}

リモデルする対象 $\mathrm{RC}$ 造校舎は, 当然その時代の建 築基準法ならびに $\mathrm{RC}$ 規準に従って設計されているわ けであるから, 建設当時の基準法, $\mathrm{RC}$ 規準を知ってお くことは重要である。そこで, ここでは建築基準法と $\mathrm{RC}$ 規準でもっとも重要と思われる変遷のポイントを述 べる。

\section{（1）耐震設計法の変遷}

現行の建築基準法は, 昭和 25 年に制定され現在にい たっている。耐震設計法は昭和 56 年の新耐震設計法以

\section{表-6 現行設計法の構造設計フロー}

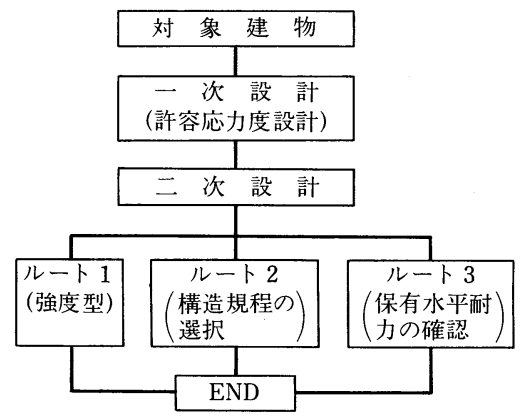

前は, 震度 $k=0.2$ の地震力に対して許容応力度設計法 で行われていたが, 昭和 56 年以降の現行設計法では建 物を強度型之勒性型に分類すると同時に, 従前の許容応 力度設計（一次設計）に加え，二次設計として一般に建 物の耐用年限中に一度遭遇するかもしれない大地震に対 する検討なども要求されている。また, 設計法も終局強 度設計法の考え方が導入されている。そのため, リモデ ルにあたっては, 対象とする校舎が昭和 56 年以前のも のでは, 当然二次設計の検討が要求され, 昭和 56 年以 降の校舎とは明確に区別して取り扱う必要がある。表一 6 に現行設計法の $\mathrm{RC}$ 造建物の構造設計フローの概略を 示しておく。

\section{表-8 $\quad \mathrm{RC}$ 規準の柱のせん断規定の变遷}

$\mathrm{RC}$ 規準
改定年

表-7『鉄筋コンクリート構造計算規準・同解説』の変遷

\begin{tabular}{|c|c|c|c|}
\hline \multicolumn{2}{|c|}{ 改 定 年 次 } & 改定次数 & 改 定 の おも な 理 由 \\
\hline 1933 & 昭和 8 年 4 月 & 初 版 & 構造強度計算の標準を示すため「鉄筋コンクリート構造計算規準」を制定 \\
\hline 1937 & 昭和 12 年 12 月 & 第 1 次 & 市街地建築物法施行規則中強度計算の条項の改定により \\
\hline 1949 & 昭和 24 年 9 月 & 第 2 次 & 日本建築規格建築 $3001 「$ 建築物の構造計算」に準拠して，その具体的運用 \\
\hline 1958 & 昭和 33 年 11 月 & 第 3 次 & 実験的・理論的研究の著しい進歩発展により \\
\hline 1962 & 昭和 37 年 11 月 & 第 4 次 & 構造用天然軽量骨材コンクリートの組み入れ \\
\hline 1971 & 昭和 46 年 5 月 & 第 5 次 & 十勝沖地震による被害の検討の結果。せん断規定の改定 \\
\hline 1975 & 昭和 50 年 8 月 & 第 6 次 & 「JASS 5」,「JIS」などの改定による \\
\hline 1979 & 昭和 54 年 11 月 & 第 7 次 & 「基礎」の部分を改定 \\
\hline 1982 & 昭和 57 年 6 月 & 第 8 次 & 建築基準法施行令の大幅な改定（新耐震設計法）による \\
\hline 1988 & 昭和 63 年 7 月 & 第 9 次 & 「JASS 5」,「JIS」などの改定による \\
\hline
\end{tabular}




\section{（2） $\mathrm{RC}$ 規準の変遷}

わが国の $\mathrm{RC}$ 造の設計は日本建築学会『鉄筋コンク リート構造計算規準・同解説』( $\mathrm{RC}$ 規準 $)$ に従って行 われているといっても過言ではない。

$\mathrm{RC}$ 規準は，表-7に示すように，昭和 8 年に制定さ れてから 9 次の改定を経て現在に至っている。 $\mathrm{RC}$ 規準 改定のなかでも昭和 46 年の第 5 次改定は建物の耐震性 能と密接な関係にある柱部材のせん断補強に関する規定 を改定している。表-8に改定前後の柱のせん断補強の 最小規定を比較して示したが，昭和 46 年以前の $\mathrm{RC}$ 規 準を用いて設計したもののなかには，はり，柱部材のせ ん断耐力が不足しているものが混在していることも考え られるので，リモデルにあたっては注意が必要である。

\section{4 リモデルのための構造部材および骨組の補強方} 法

校舎をリモデルする場合，既存構造部材および骨組を 補強し, 強度あるいは勒性能を增大させたいという要求 は当然あるわけで，そのような既存構造部材および骨組 の各種補強方法に関しては文献 3)，7)，8），9）などに詳 細に述べられているので参照していただきたい。現在ま でに実用化あるいは研究されている各種補強方法として は表-9のようなものがある。図-17に各種補強例の概 略図を示した。

\section{5 リモデルにおける構造に関する今後の課題}

$\mathrm{RC}$ 造校舎をリモデルする場合の構造に関係する事項

\section{表-9 各種補強方法}
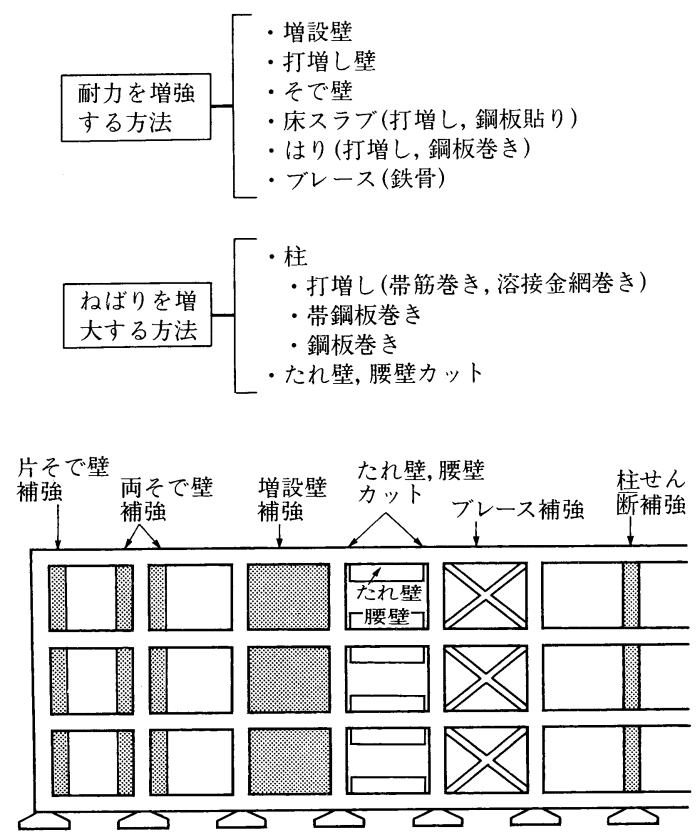

図-17 各種補強方法の概略図
について述べてきたが，構造に関する今後の課題として 次のことが挙げられる。いずれにしても，構造に関する 今後の課題は多い。

1）既存 $\mathrm{RC}$ 造建物をリモデルする場合には当然リ モデルに関する豊富な知識を必要とする。たとえ ば，構造であれば，補修・補強についてはもちろ ん，ファスニング技術の知識までも必要となる。現 在の建築設計教育はおもに建物を新しく造る技術の 取得に重点が置かれているが，今後はリモデルを対 象とした教育も行い，優れたリモデルの知識を持つ 人材を早急に育成する必要がある。

2）そのためには，リモデルに関する計画論はもちろ んのこと, 構造の補修・補強などに関するマニュア ルを整備し，一般の設計者でも学校建築のリモデル が容易に理解できるようにする必要がある。

3）現在ある既存校舎は 5 章 2 節でも述べたように, 何種類かの平面タイプに分類されているので，それ らの各タイプの校舎において, 構造的にどの程度の リモデルまで可能なのかを追求し，明らかにする必 要がある。このことは計画的りモデルをするうえで 有用であろう。

4）リモデル用の構造マニュアルは，補修・補強なら びにファスニング技術の詳細なディテールを具体的 に示すと同時に力学的解説も必要である。

5）構造的なりモデルの技術として，制震，免震など は優れたものであるから，これらの技術を積極的に 導入していく必要もあろう。

6）増設をする場合などは，使用材料として各種のも のが考えられる。すなわち，リモデルには今後骨組 のハイブリッド化が多用されるであろうから，それ らの研究も必要である。

\section{参 考 文 献}

1）文部省管理局教育施設部：既存鉄筋コンクリート造・鉄 骨造学校建物の耐力度測定方法, 昭 58.9

2）日本建築防災協会 : 既存鉄筋コンクリート造建築物の耐 震診断基準・改修設計指針, 1977. 4

3）岡田恒男：既存 RC 造学校建築のリニューアル, 北陸 建築フォーラム資料, 1993. 4

4) 学校建築研究会 (東北工業大学) : 既存 RC 造学校建築 物を社会的変化に対応させるための手法に関する砳究報 告書, 平 2.6

5) 日本建築学会: 学校建築 計画と設計, 昭 54.2

6) 田中礼治 : 1978 年 6 月宮城県沖地震における仙台市内 の小中学校の被害調査および今後の問題点について (そ の 1), 日本建築学会東北支部研究発表会, 昭 53.11

7）日本コンクリート工学協会 : 既存鉄筋コンクリート構造 物の耐震補強ハンドブック，技報堂出版，1984.10

8）特集 既存建物の耐震補強, 建築技術, 1982 年 9 月号

9）小倉弘一郎（監修）：既存 RC 建物の耐震補強之診断, 技術書院, 昭 63.5 